\title{
Çocuklarda asetabulum kırığı: Ender bir olgu sunumu
}

\author{
Acetabular fracture in childhood: A rarely seen case report
}

\section{Serdar Hakan Başaran*, Mustafa Gökhan Bilgili, Cemal Kural, Alkan Bayrak, Mustafa Cevdet Avkan}

Ortopedi ve Travmatoloji Anabilim Dalı (Yrd. Doç. Dr. S. H. Başaran), Karabük Üniversitesi Tıp Fakültesi, TR-78050 Karabük, Ortopedi ve Travmatoloji Kliniği (Dr. M. G. Bilgili, Doç. Dr. C. Kural, Dr. A. Bayrak, Doç. Dr. M. C. Avkan), Bakırköy Dr. Sadi Konuk Eğitim ve Araştırma Hastanesi, TR-34147 İstanbul

\section{Özet}

Asetabulum kırığı çocuklarda ve adolesanlarda oldukça nadir görülür. Bu kırık genellikle yüksek enerjili travma sonrası ortaya çıkar ve uzun dönem prognoz hastanın kırık anındaki yaşına, asetabulum Y kıkırdağının zedelenmesine ve deplasman miktarına göre değişir. Bu çalışmada yedi yaşında kız çocuğunun yüksekten düşme sonucu gelişen, nondeplase iliak kanat kırığı ile birlikte olan sol asetabulum anterior duvar kırığının traksiyon tedavisinin sonuçları fonksiyonel ve radyolojik olarak değerlendirildi.

Anahtar sözcükler: Çocuk, asetabulum, kırıklar, tedavi

\begin{abstract}
Acetabular fractures are rarely seen in children and adolescents. This fracture usually developes after a high energy trauma and the prognosis is related to the age,the amount of deplacement of the fracture and the injury of the Y cartilage of the acetabulum. In this study we evaluated functional and radiological results of a seven years old girl with left acetabular anterior wall and nondeplaced iliac wing fracture after fall from height which is treated by traction.
\end{abstract}

Keywords: Child, acetabulum, fractures, treatment

Geliş tarihi/Received: 16 Şubat 2012; Kabul tarihi/Accepted: 07 Ocak 2013

*İletişim adresi:

Dr. Serdar Hakan Başaran, Ortopedi ve Travmatoloji Anabilim Dalı, Karabük Üniversitesi Tıp Fakültesi, TR-78050 Karabük. E-posta: serdarhakan2004@hotmail.com

\section{Giriş}

Pelvis kırıkları tüm pediatrik kırıkların \%0,2'sini oluşturmaktadır. Kafa travması pelvik kırıklı çocuklarda en sık ölüm nedenidir. Pediatrik pelvik kırıkların en sık nedeni trafik kazalarıdır [1]. Asetabulum kırı̆̆ı çocuklarda ve adolesanlarda, erişkinlerin aksine oldukça nadir görülür. Bunun sebebi çocuklarda eklem laksitesi daha fazla olması, eklem kıkırdağının daha kalın olması ve ligamentlerin daha sağlam olmasına bağlı gibi görünmektedir [2]. Çocuk asetabulum kırıklarında triradiate kıkırdağın fizis yaralanmasına asetabulumun büyümesindeki bozulmalar göz önünde bulundurulmalı, hastalar yakından takip edilmelidir [3]. Bu hastalarda tedavi öncelikli olarak yatak istirahati ve traksiyon tedavisidir.

$\mathrm{Bu}$ çalışmada yedi yaşında kız çocuğunun yüksekten düşme sonucu gelişen, nondeplase iliak kanat kırı̆̆ yatak istirahati tedavisinin sonuçları fonksiyonel ve radyolojik olarak değerlendirildi. 


\section{Olgu sunumu}

Yedi yaşında kız çocuğu yüksekten düşme sonucu sol kalçasında ani başlayan ağrı ve yürüyememe şikayetleri ile acil ortopedi servisinde görüldü. Hastanın yapılan fizik muayenesinde sol kalça hareketlerinde kısıtlllık, eklemde hafif derecede şişlik ve hassasiyet vardı. İstenen pelvis, kalça grafisi ve bilgisayarlı tomografi (BT) tetkiklerinde sol asetabulum anterior duvarda $2 \mathrm{~mm}$ 'den daha az kaymış, sol iliak kanatta ise kaymamış kırık tespit edildi (Resim 1). Hastaya cilt traksiyonu uygulandı ve yatak istirahati verildi. Akut ağrı geçtikten sonra egzersiz programına başlandı. Hasta kaynama, ağrı, mobilizasyon zamanı, eklem hareket açıklığı yönünden değerlendirildi. Hastanın dördüncü hafta kontrolünde kırığın kaynadığı görüldü ve kısmi yükle basmasına, altıncı haftadan sonra da tam yükle basmasına izin verildi. Altıncı hafta kontrolünde eklem hareketlerinde iç rotasyonda 15 derece kısıtlılık mevcuttu diğer hareketlerde k1sitlılık yoktu. Yürürken ve hareketle kalça ağrısı minimaldi. Harris kalça skoru değerlendirmesinden 89 puan almıştı. Hasta üçüncü ay kontrolünde eklem hareket açıklı̆̆ 1 ve kas gücü tamdı. Ayrıca yürürken ve oyun oynarken ağrı tarif etmiyordu. Harris kalça skoru değerlendirmesinden 100 puan almıştı. Röntgen incelemesinde hastanın kalçasında travma sonrası değişikliklere rastlanmadı. Hastanın durumunda birinci ve ikinci y1l kontrolünde de herhangi bir değişiklik olmamıştı (Resim 2). Olgunun son takibindeki radyolojik incelemede posttravmatik artrit ve asetabuler displaziye rastlanmadi.
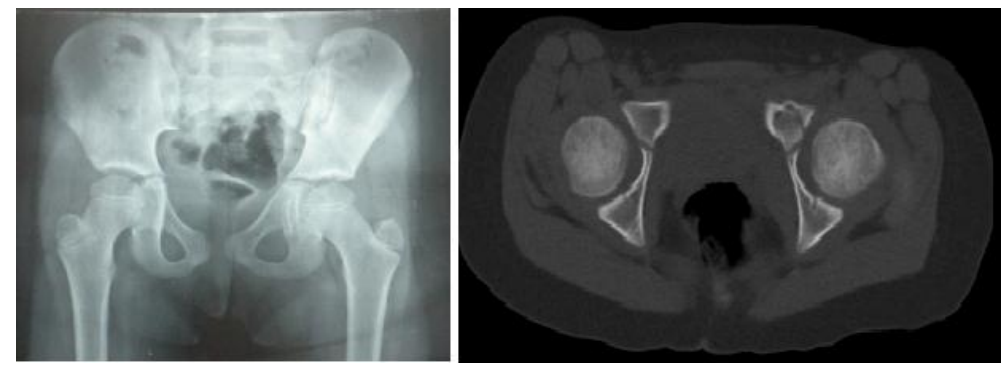

Resim 1. Yedi yaşında kız çocuğu yüksekten düşme sonucu gelişen röntgen ve BT görüntülerinde sol asetabulum anterior duvarda 2 mm'den daha az kaymış, sol iliak kanatta ise kaymamış kırık görülmekte.
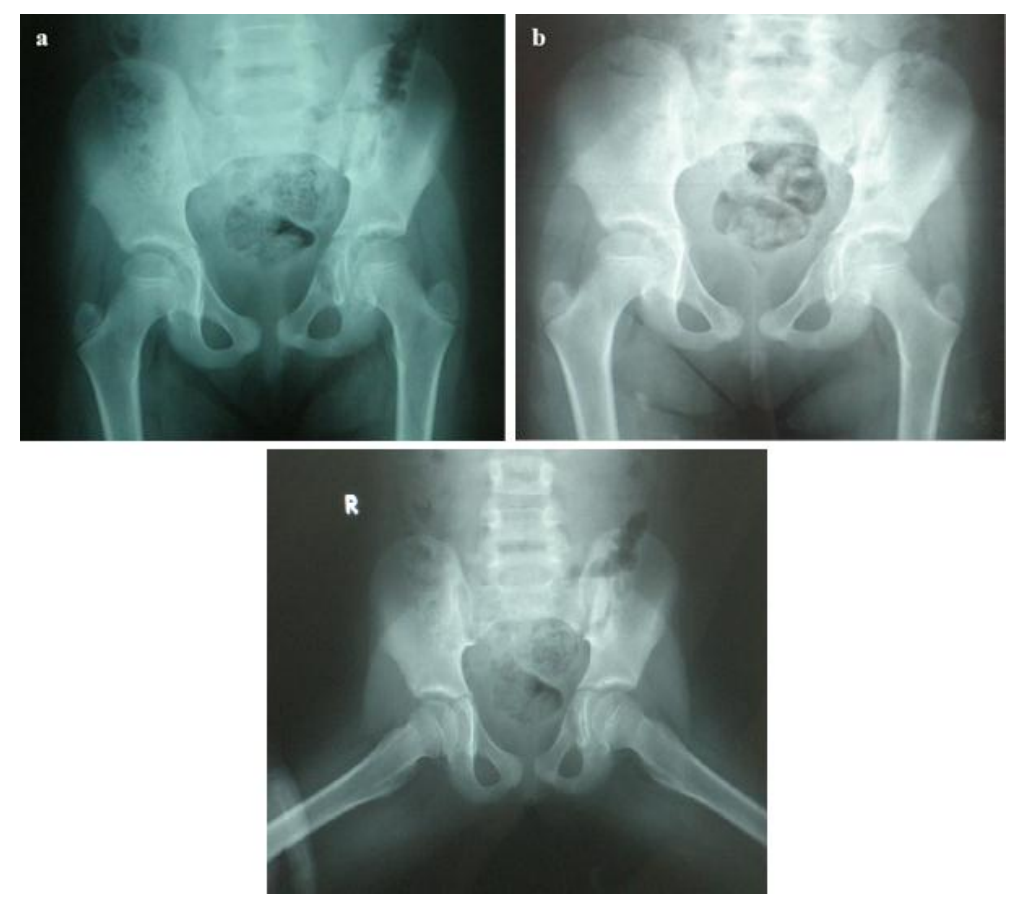

Resim 2. Aynı hastanın altıncı hafta (a) ve ikinci yıl (b) kontrol grafileri. 


\section{Tartışma}

Asetabulum kırıkları erişkinlerde iyi bilinirken, çocuklarda ve adolesanlarda oldukça nadir görülür. Asetabulum kırıkları değişik serilerde tüm pelvis kırıklarının \%1-15'ini oluşturur [3-6]. Çocuk pelvisi erişkinlerden belirgin olarak farklıdır; daha yumuşak ve eklem laksitesi nedeniyle önemli miktarda yer değiştirmeye izin verir, bu nedenle pelvik halkada tekli kırıklar oluşur [3, 7, 8]. Diğer önemli farkı da triradiate kartilajın zarar görmesine bağlı olarak asetabulum büyümesinde bozulmalar ve asetabuler displaziler görülebilmesidir [3, 8, 9]. Buna karşın çocuk pelvisi immatür olduduğundan remodelasyon özelliği vardır.

Çocuklardaki asetabum kırığı oluşturan yaralanma mekanizmaları erişkinlerdeki gibidir, kırık femur başından asetabuluma doğru aktarılan güç ile oluşur. Ekstremitenin pozisyonu ve travmanın şiddeti kırık paternini, lokalizasyonunu ve kırı̆̆ın şiddetini belirler. Yüksek enerjili travma ile oluşan asetabulum kırıklarında genellikle başka major yaralanmalar içeririken, izole asetabulum kırıları genellikle düşük enerjili yaralanmalar ile olur. Letournel-Judet sınıflandırmasına ek olarak triradiate kartilaj kırıkları için Salter-Harris sınıflamasıda kullanılabilir. Bununla birlikte çocuklarda asetebulum kırıkları nadiren çıkığa eşlik edebilir [10, 11]. Bu kırıklar genellikle posterior duvar kırığı olarak görülür. Ayırıca çocuklarda asetebulum anterior duvar kırı̆̆ı diğer kırık tiplerine göre çok daha nadir görülür [6]. Bizim olgumuzda asetabulum anterior duvar kırığı mevcuttu, ranzadan düşme sonucu gelişmişti ve iliak kanattaki kırık haricinde başka ek yaralanması yoktu.

Tanı genellikle standart grafiler ile konur fakat eklem aralığında uyumsuzluk veya farklılık varsa, eklem faresi özellikle de kıkırdakımsı pelvisi olan çocuklarda standart grafilerde kolaylıkla gözden kaçmış olabilir [8]. Eğer her iki kalça ekleminde de uyumsuzluk var ise artrografi veya BT incelemesi yapılmalıdır [1]. Yeni yayınlarda özellikle çıkığın da eşlik ettiği asetabulum kırıklarında BT incelemesine ek olarak manyetik rezonans incelemeside önerilmektedir [10, 12]. Tartışmalı olmakla birlikte bütün grafilerde $2 \mathrm{~mm}$ ve daha az yer değiştirme kabul edilebilir ve operasyon önerilmez [12-14]. Bizim olgumuzda da kırık direk grafide net seçilememekte, BT incelemesinde ise kolayca tespit edilmekteydi (Resim 1).

Çocukluk çağı asetabulum kırıklarının tedavisinde amaç eklem uyumunu ve kalça stabilitesini sağlamak. Bununla birlikte bu kırıklar hemen her zaman kaynarlar. Asetabulum kırıklı çocukların tedavi şeması da genellikle erişkilerdeki gibidir. Yatak istirahati veya yük vermeden kanadyenler ile ambulasyon non-deplase ve minimal $(<2$ $\mathrm{mm}$ ) deplase kırıkların tedavisinde uygulanır. Koltuk değnekleri ile ambulasyon sadece büyük çocuklarda uygulanır. Genellikle 6-8 hafta yük verilmez. Daha küçük çocuklarda 5-6 hafta yük verilmez bununla birlikte adolesanlarda ( $>12$ yaş) 3-4 hafta sonra parsiyel yük vermeye başlanabilir. Kırıkta deplasman $2 \mathrm{~mm}$ ve daha az ise redüksiyon için distal femurdan iskelet traksiyonu yapılır. Egzersiz programına hastaların ağrısı azalır azalmaz başlanır. Bizim olgumuzda da kırık $2 \mathrm{~mm}$ 'den daha az yer değiştirdiği için biz cilt traksiyonu uyguladık. Eğer kırıkta $2 \mathrm{~mm}$ 'den daha fazla yer değiştirme varsa, kırık instabil ise veya eklem içi kemik parça varsa açık redüksiyon ve internal fiksasyon yapılır $[8,6,14]$.

Özellikle 10 yaşından küçük çocuklarda görülen asetabulum travmalarından sonra triradiate kartilajda oluşan kemik köprü veya büyüme durmasına bağlı olarak asetabular displazi gelişebilir. Bucholz [15]'a göre 11 yaşından daha büyük çocuklarda görülen asetabulum kırıklarında ciddi asetabuler displazi görülme riski azalmaktadır. Asetabulum kırığ1 sonrası prematür triradiate kartilaj kapanmas1, osteonekrozis, travmatik artrit, siyatik sinir paralizisi, miyozitis ossifikans gibi komplikasyonlar görülebilir. Çocuklarda görülen bütün asetabulum kırıklarında fonksiyonel sonuçlar genellikle radyolojik sonuçlardan daha iyidir. 
Sonuç olarak daha nadir olarak görülen anterior asetabuler duvar kırığı olgumuz da kırık minimal deplase ve triradiat kartilajı içermediğinden herhangi bir komplikasyon gelişmedi. Fonksiyonel sonuç Harris kalça skoruna göre mükemmeldi. Bu tür hastaların tedavisinde yatak istirahati ve cilt traksiyonu ile tedavinin iyi sonuçlar verebileceğini düşünüyoruz.

\section{Kaynaklar}

1. Subaşı M, Cebesoy O, Işık M, Gerçekcioğlu A. Çocukluk çağı pelvis kırıkları. TOTBID Dergisi 2008; 7: 116-20.

2. Heeg M, de Ridder VA, Tornetta P 3rd, de Lange S, Klasen HJ. Acetabular fractures in children and adolescents. Clin Orthop Relat Res 2000; 376: 80-6.

3. Liporace FA, Ong B, Mohaideen A, Ong A, Koval KJ. Development and injury of the triradiate cartilage with its effects on acetabular development: review of the literature. J Trauma 2003; 54: 1245-9.

4. Bryan WJ, Tullos HS. Pediatric pelvic fractures: review of 52 patients. J Trauma 1979; 19: 799-805.

5. Craig CL. Hip injuries in children and adolescents. Orthop Clin North Am 1980; 11: 743-54.

6. Heeg M, Klasen HJ, Vesser JD. Acetabular fractures in children and adolescents. J Bone Joint Surg Br 1989; 71: 418-21.

7. Currey JD, Butler G. The mechanical properties of bone tissue in children. J Bone Joint Surg Am 1975; 57: 810-4.

8. Schlickewei W, Keck T. Pelvic and acetabular fractures in childhood. Injury 2005; 36: A57-63.

9. Sener M, Karapinar H, Kazimoglu C, Yagdi S, Akgun U. Fracture dislocation of sacroiliac joint associated with triradiate cartilage injury in a child: a case report. J Pediatr Orthop B 2008; 17: 65-8.

10. Hearty T, Swaroop VT, Gourineni P, Robinson L. Standard radiographs and computed tomographic scan underestimating pediatric acetabular fracture after traumatic hip dislocation: report of 2 cases. J Orthop Trauma 2011; 25: 68-73.

11. Uruç V, Karabulut S. Asetabulum posterior dudağında kırık birlikteliğinde ihmal edilmiş travmatik kalça çıkı̆̆ı: Çok nadir bir olgu. J Clin Exp Invest 2011; 2: 228-31.

12. Rubel IF, Kloen P, Potter HG, Helfet DL. MRI assessment of the posterior acetabular wall fracture in traumatic dislocation of the hip in children. Pediatr Radiol 2002; 32: 435-9.

13. Brooks E, Rosman M. Central fracture-dislocation of the hip in a child. J Trauma 1988; 28: 1590-2.

14. Karunakar MA, Goulet JA, Mueller KL, Bedi A, Le TT. Operative treatment of unstable pediatric pelvis and acetabular fractures. J Pediatr Orthop 2005; 25: 348.

15. Bucholz RW, Ezaki M, Ogden JA. Injury to the acetabular triradiate physeal cartilage. J Bone Joint Surg Am 1982; 64: 600-9. 